\title{
Liaison Activities with the Institute of Physical Chemistry of the Russian Academy of Sciences: Midyear Report
}

C. H. Delegard

Date Published

May 1996

Prepared for the U.S. Department of Energy Assistant Secretary for Environmental Management Office of Science and Technology

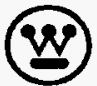

U.S. Depertment of Energy under Contract DE-AC06-87RL10930 
THIS PAGE INTENTIONALLY

LEFT BLANK 
LECAL DISCLANMER

This report was prepared as an account of work sponsored by an agency of the United States Government. Neither the United States Government nor any aganay thereof, nor any of their employees, nor any of their contractors, subcontractors or their ermployees, makes any warranty, express of implied, or assumes eny logad liability or responsibility for the accuracy, completeness, or any third party's use or the results of such use of any information, apperatus, product, or process disclosed, or represents that its use would not infringe privetely owned rights. Reference herein to any specific commercial product, process, or service by trade name, trademark, manufacturer, or otherwise, does not necessarily constitute or imply its endorsement, pecommendation, or favoring by the United States Government or any agency thereof or its contractors or subcontraciors. The views and opinione of euthors expressed herein do not necessarily state or reflect those of the United States Government or any agency thereof.

This report hes been reproduced from the best available copy. Available in paper copy and microtiche.

Available to the U.S. Department of Energy and its contractors from

U.S. Department of Energy

Office of Scientific and Technical Information (OST)

P.O. Box 62

Oak Ridge, TN 37831

(615) 576-8401

Printed in the Uhinted States of Amence

DISCLM-3.CHP $\{1-91\}$ 
THIS PAGE INTENTIONALLY LEFT BLANK 


\section{RELEASE AUTHORIZATION}

Document Number: WHC-SP-1184

Liaison Activities with the Institute of Physical

Document Title: Chemistry of the Russian Academy of Sciences:

Midyear Report

Release Date: $\quad 5 / 29 / 96$

This document was reviewed following the procedures described in WHC-CM-3-4 and is:

APPROVED FOR PUBLIC RELEASE

WHC Information Release Administration Specialist:
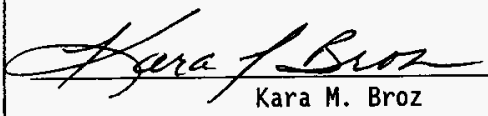

May 29, 1996

Kara M. Broz 
THIS PAGE INTENTIONALLY LEFT BLANK 


\section{CONTENTS}

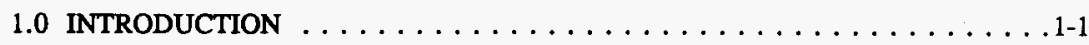

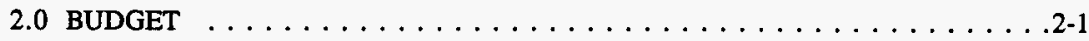

3.0 WORK ELEMENTS $\ldots \ldots \ldots \ldots \ldots \ldots \ldots \ldots \ldots \ldots \ldots \ldots \ldots \ldots \ldots \ldots$

4.0 DIRECTION SUBTASK $\ldots \ldots \ldots \ldots \ldots \ldots \ldots \ldots \ldots \ldots . \ldots . . \ldots .1$

4.1 TASK REVIEW AND SELECTION $\ldots \ldots \ldots \ldots \ldots \ldots \ldots \ldots$ 4-1

4.2 TECHNICAL LITERATURE AND INFORMATION $\ldots \ldots \ldots \ldots \ldots .4-2$

4.3 VISIT OF IPC/RAS SCIENTISTS TO THE UNITED STATES $\ldots \ldots \ldots \ldots 4-4$

4.4 DIALOGUE ON PLUTONIUM(V) STABILITY AND PROPERTIES

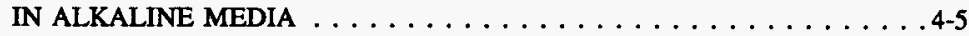

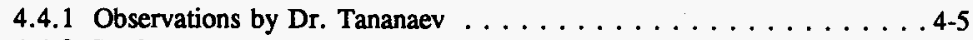

4.4 .2 Reply . . . . . . . . . . . . . . . . . . .4-7

4.5 PROVISION OF A LIQUID SCINTILLATION COUNTER AND

ULTRAFILTERS TO THE IPC/RAS $\ldots \ldots \ldots \ldots \ldots \ldots \ldots \ldots$. . $\ldots \ldots$

5.0 DISSEMINATION SUBTASK $\ldots \ldots \ldots \ldots \ldots \ldots \ldots \ldots \ldots \ldots$. $\ldots \ldots \ldots$

5.1 TECHNICAL PRESENTATIONS $\ldots \ldots \ldots \ldots \ldots \ldots \ldots \ldots$. $\ldots \ldots$.

5.2 TECHNICAL PUBLICATIONS $\ldots \ldots \ldots \ldots \ldots \ldots \ldots \ldots \ldots \ldots \ldots \ldots \ldots .2$

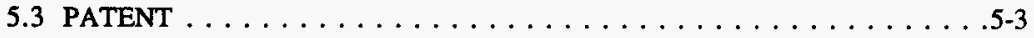

6.0 VERIFICATION SUBTASK $\ldots \ldots \ldots \ldots \ldots \ldots \ldots \ldots \ldots$ 6-1

6.1 ATTAINING EQUILIBRIUM $\ldots \ldots \ldots \ldots \ldots \ldots \ldots \ldots \ldots$ 6-1

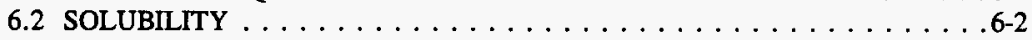

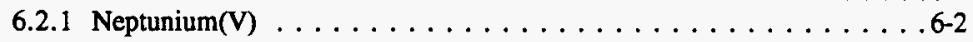

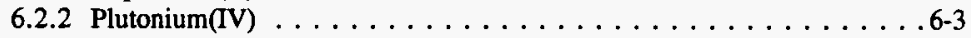

6.2 .3 Plutonium(V) . . . . . . . . . . . . . . . . . . .

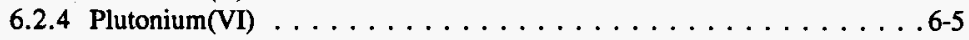

6.2 .5 Plutonium(IV) Carbonate $\ldots \ldots \ldots \ldots \ldots \ldots \ldots \ldots \ldots$

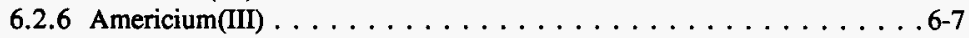

6.3 COPRECIPITATION . . . . . . . . . . . . . . . 6-8

6.4 GAMMA RADIATION CHEMISTRY $\ldots \ldots \ldots \ldots \ldots \ldots \ldots$ 6-10

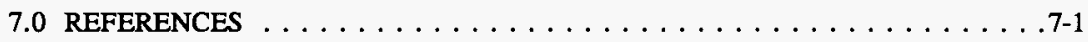




\section{LIST OF FIGURES}

4-1 Plutonium Hydrous Oxide Solubility Dependence on Electrode Potential

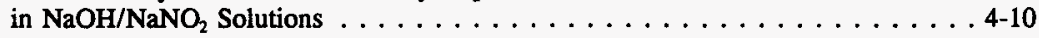

6-1 Solubility Variation with Aging of $\mathrm{PuO}_{2} \cdot \mathrm{xH}_{2} \mathrm{O}$ in $5 \mathrm{M} \mathrm{NaOH} \ldots \ldots \ldots \ldots$ 6-1

6-2 Solubility of $\mathrm{Np}(\mathrm{V})$ Salts in $\mathrm{NaOH}$ Solutions $\ldots \ldots \ldots \ldots \ldots .6 .6 .2$

6-3 Solubility of $\mathrm{Pu}(\mathrm{IV})$ Hydrous Oxide in $\mathrm{NaOH}$ Solutions . . . . . . . . . 6-4

6-4 Solubility of $\mathrm{Pu}(\mathrm{V})$ Salts in $\mathrm{NaOH}$ Solutions $\ldots \ldots \ldots \ldots \ldots$. . . . . . . . .

6-5 Solubility of $\mathrm{Pu}(\mathrm{VI})$ Salts in $\mathrm{NaOH}$ Solutions $\ldots \ldots \ldots \ldots \ldots$ 6-6

6-6 Enhancement of Plutonium Concentration Above Pu(IV) Hydrous Oxide Because of Carbonate Complexation in $\mathrm{NaOH} / \mathrm{Na}_{2} \mathrm{CO}_{3}$ Solutions . . . . . . 6-7

\section{LIST OF TABLES}

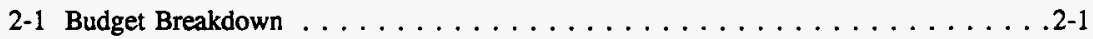

4-1 Predicted and Measured Electrode Potentials and Plutonium Concentrations in $\mathrm{NaOH} / \mathrm{NaNO}_{2}$ Solutions $\ldots \ldots \ldots \ldots \ldots \ldots \ldots \ldots \ldots \ldots . \ldots \ldots$

6-1 Neptunium and Plutonium Decontamination Factors from Alkaline Solution and Genuine and Simulant Hanford Site Tank Waste . . . . . . . . . . 6-9 


\section{LIST OF TERMS}

$\begin{array}{ll}\text { ACS } & \text { American Chemical Society } \\ \text { C/D } & \text { calcination and dissolution } \\ \text { DOE } & \text { U.S. Department of Energy } \\ \text { ESP } & \text { Efficient Separations and Processing } \\ \text { FY } & \text { fiscal year } \\ \text { IPC/RAS } & \text { Institute of Physical Chemistry of the Russian Academy of Sciences } \\ \text { LSC } & \text { liquid scintillation counter } \\ \text { SRTC } & \text { Savannah River Technical Center } \\ \text { TTP } & \text { technical task plan }\end{array}$


WHC-SP-1184

This page intentionally left blank. 


\section{LIAISON ACTIVITIES WITH THE INSTITUTE OF PHYSICAL CHEMISTRY OF THE RUSSIAN ACADEMY OF SCIENCES: MIDYEAR REPORT}

\subsection{INTRODUCTION}

The task "IPC/RAS Liaison and Tank Waste Testing" is a program being conducted in fiscal year (FY) 1996 with the support of the U.S. Department of Energy (DOE) Office of Science and Technology, EM-53 Efficient Separations and Processing (ESP) Crosscutting Program, under the technical task plan (TTP) RL46C342. The principal investigator is Cal Delegard of the Westinghouse Hanford Company. The task involves a technical liaison with the Institute of Physical Chemistry of the Russian Academy of Sciences (IPC/RAS) and their DOE-supported investigations into the fundamental and applied chemistry of the transuranium elements (primarily neptunium, plutonium, and americium) and technetium in alkaline media.

The task has three purposes:

1. Providing technical information and technical direction to the IPC/RAS.

2. Disseminating IPC/RAS data and information to the DOE technical community.

3. Verifying IPC/RAS results through laboratory testing and comparison with published data.

This report fulfills the milestone "Prepare Progress Report to Focus Area," due June 1, 1996. 
This page intentionally left blank. 


\subsection{BUDGET}

The total task funding is $\$ 250,000$ of which $\$ 50,000$ was allocated to capital purchases. The capital monies were intended for the acquisition and delivery of a liquid scintillation counter (LSC) to the IPC/RAS.

Task budget accounts (labor, travel, sample analysis, publishing services, organizational overheads) total $\$ 200,000$ for FY 1996 . The budget status through April 1996 is given in Table 2-1. The increased amount spent to date in the travel budget was because four, rather than two, IPC/RAS scientists were brought to the United States for discussions.

Expenditures for publishing also are above the projected rate. The higher spending for travel and publishing is balanced by markedly lower spending in sample analyses. Savings on sample analyses were achieved by extensive use of published data, rather than separate laboratory studies, to verify IPC/RAS results. The use of literature data also saved labor expenditures.

Table 2-1. Budget Breakdown.

\begin{tabular}{|c|c|c|c|}
\hline BWh & Hod & 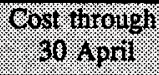 & Diference \\
\hline Labor & 43,000 & 36,100 & 6,900 \\
\hline Travel & 16,500 & 24,500 & $(8,000)$ \\
\hline Sample Analysis & 25,000 & 4,800 & 20,200 \\
\hline Publishing Services & 7,200 & 19,600 & $(12,400)$ \\
\hline Organization Overhead & 9,600 & 8,000 & 1,600 \\
\hline Miscellaneous Contracts & & 1,400 & $(1,400)$ \\
\hline G\&A/CSP & 13,200 & 15,100 & $(1,900)$ \\
\hline Total & 114,500 & 108,800 & 5,000 \\
\hline
\end{tabular}

Note:

'General and administrative/common support pool Hanford Site overhead charges.

Additional capital funds $(\$ 15,000)$ were requested early in the fiscal year to cover the higher-than-anticipated costs of the LSC $(\$ 52,000$ for the delivered instrument indicated by two candidate vendors versus about $\$ 35,000$ budgeted). However, through the efforts of this task and the Westinghouse Hanford Company procurement organization, a third prominent manufacturer of LSC devices was located with a sales and service office in Moscow, Russia was located. This vendor offered a suitable LSC instrument unburdened by the approximately $\$ 20,000$ surcharge apparently imposed by the two other candidate vendors to deliver in Moscow, Russia, rather than the United States. The LSC was purchased, 
delivered, and installed at the IPC/RAS in February at a cost of about $\$ 39,000$ (including delivery and Westinghouse Hanford Company procurement overhead charges). The $\$ 15,000$ additional capital funds have been returned to the program for reallocation. 


\subsection{WORK ELEMENTS}

The following three work elements were identified and described in the TTP.

1. Direct the IPC/RAS principal investigators by providing difficult-to-obtain DOE contractor documents and information on the Hanford Site tank waste properties and system. This also includes review and guidance for the IPC/RAS tasks and provision of essential laboratory equipment to the IPC/RAS.

2. Disseminate the IPC/RAS results by technical review, editing, and publication of the IPC/RAS reports and presentation of the IPC/RAS results at program, DOE Site, national, and international meetings and symposia.

3. Verify the results of the IPC/RAS work by studies of the technical literature and performance of laboratory tests with simulant and genuine Hanford Site tank waste. 
This page intentionally left blank. 


\subsection{DIRECTION SUBTASK}

Activities under the direction subtask included a technical review and critique of the tasks proposed by the IPC/RAS for FY 1996, provision of technical literature and information to the IPC/RAS scientists, a visit of the four IPC/RAS scientists to the United States for technical discussions with DOE and DOE contractor personnel, technical dialogues, and supply of the liquid scintillation counter to the IPC/RAS.

\subsection{TASK REVIEW AND SELECTION}

Eight proposals were made by the IPC/RAS for work in FY 1996. The eight proposals, as well as the names of the laboratory heads and lead scientists involved, were provided late in FY 1995 (Delegard 1995b) and are listed as follows:

1. Investigation of homogeneous and heterogeneous catalysis (Krot/Shilov)

- to destroy organic compounds in Hanford Site tank waste

- to reduce and stabilize neptunium in the (IV) state.

2. Investigation of the effects of tank waste anions (for example, nitrate, nitrite, carbonate, complexants) on the removal of actinides from solution by the Method of Appearing Reagents; determination of the behaviors of ${ }^{90} \mathrm{Sr}$ and ${ }^{137} \mathrm{Cs}$ is these reactions. (Krot/Bessonov)

3. Investigation of the stability of plutonium(V). (Krot/Budantseva)

4. Investigation of sorbents for neptunium, plutonium, and americium prepared from lanthanum and uranium hydroxide with inert carriers. (Krot/Tananaev)

5. Investigation of isolation methods for technetium (anion exchange, extraction, coprecipitation, cementation on metals, electrodeposition). (Peretrukhin)

6. Investigation of technetium response to thermochemical processing. (Kryutchkov)

7. Investigation of electrochemical denitration of waste in the presence of uranium, neptunium, plutonium, technetium, and chromate. (Peretrukhin)

8. Investigation of alpha radiolysis on actinide behavior in alkaline and alkaline/carbonate media. (Pikaev)

Critiques and comments were provided to the IPC/RAS in November 1995 on the scope, utility, and, for some projects, the likelihood of support. In addition, some DOE contractor technical reports were provided at this time to advise the IPC/RAS scientists of related work 
already performed in these areas. A separate technical dialogue between Cal Delegard (the liaison principal investigator) and the IPC/RAS scientist Dr. Ivan G. Tananaev also took place. This exchange concerned the stability of pentavalent plutonium in alkaline media.

As a result of these remarks and reports, task \#4 (on sorbents) was withdrawn because similar work already had been performed by the Sandia and Los Alamos National Laboratories. Task \#6 (on technetium behavior in thermochemical processing) also was withdrawn based on advice that calcination processing of Hanford Site tank waste was unlikely. The discussions between Dr. Tananaev and Cal Delegard were taken into account in designing the studies proposed for task \#3. The major points of these discussions are given in Section 4.4 .

Modifications to the remaining six tasks were made and more detailed proposals (including cost and schedule) were submitted in November and December 1995. Recommendations were made to the DOE and to Dr. Jack Watson, the Program Coordinator for International Programs, about which tasks to support. The four most favored tasks were \#2 (continued studies of coprecipitation by the Method of Appearing Reagents), \#1 (catalytic methods to destroy organics and reduce neptunium), \#5 (technetium removal methods), and \#3 (stability of pentavalent plutonium). These four tasks were selected for support.

Contract negotiations were made and concluded by Dr. Tom Albert of Thomas Albert and Associates, Palm Harbor, Florida. Work on the four tasks commenced on March 1, 1996.

\subsection{TECHNICAL LITERATURE AND INFORMATION}

A number of technical reports (generally from DOE contractors) were provided to the IPC/RAS to communicate the status of research in the DOE technical community, to provide the composition and properties of Hanford Site tank waste, and to supply information on waste processing plans. The reports furnished to the IPC/RAS so far in FY 1996 are listed.

- Ashby, E. C., E. K. Barefield, C. L. Liotta, H. M. Neumann, F. Doctorovich, A. Konda, K. Zhang, J. Hurley, D. Boatright, A. Annis, G. Pansino, M. Dawson, and M. Juliao, "Mechanistic Studies Related to the Thermal Chemistry of Simulated Nuclear Wastes That Mimic the Contents of a Hanford Site Double-Shell Tank," pp. 249-284 in Emerging Technologies in Hazardous Waste Management IV, D. W. Tedder and F. G. Pohland, editors, American Chemical Society, Washington, D.C. (1994).

- Marsh, S. F., Z. V. Svitra, and S. M. Bowen, "Effects of Soluble Organic Complexants and Their Degradation Products on the Removal of Selected Radionuclides from High-Level Waste," LA-13000, Los Alamos National Laboratory, Los Alamos, New Mexico (1995). 
- Karraker, D. G., "Solubility of Plutonium in Waste Evaporation," WSRC-TR-93-578, Rev. 0, Savannah River Technology Center, Aiken, South Carolina (1993).

- Hobbs, D. T. and D. G. Karraker, "Recent Results on the Solubility of Uranium and Plutonium in Savannah River Site Waste Supernate," WSRC-MS-94-061, Savannah River Technology Center, Aiken, South Carolina (1994).

- Karraker, D. G., "Uranium Solubility Studies During Waste Evaporation," WSRC-TR-93-433, Savannah River Technology Center, Aiken, South Carolina (1993).

- $\quad$ Karraker, D. G., "Solubility of Neptunium in Alkaline High-Level Waste (U)," WSRC-TR-94-0526, Rev. 1, Savannah River Technology Center, Aiken, South Carolina (1994).

- Worl, L. A., S. M. Bowen, J. M. Berg, D. D. Padilla, and M. R. Cisneros, "Actinide Removal from Hanford Supernatant Tank Waste, " LA-UR-95-3743, Los Alamos National Laboratory, Los Alamos, New Mexico (1995).

- Delegard, C. H., "Calcination/Dissolution Chemistry Development Fiscal Year 1995," WHC-EP-0882, Westinghouse Hanford Company, Richland, Washington (1995).

- Delegard, C. H., "Calcination-Dissolution Treatment of Hanford Site Tank Waste," WHC-SA-2911, Westinghouse Hanford Company, Richland, Washington (1996).

- Camaioni, D. M., W. D. Samuels, S. A. Clauss, B. D. Lenihan, K. L. Wahl, J. A. Campbell, and W. J. Shaw, "FY 95 Waste Aging Studies," PNL-10794, Pacific Northwest Laboratory, Richland, Washington (1995).

- Samuels, W. D., D. M. Camaioni, S. A. Clauss, J. C. Linehan, K. L. Wahl, B. D. Lenihan, and W. J. Shaw, "Investigation into the Chemical, Thermal, and Radiological Changes of Organic Chemicals Added to the Underground Storage Tanks at Hanford," PNL-SA-23331, Pacific Northwest Laboratory, Richland, Washington (1996).

The following reports were provided by the reports' author to Professors Peretrukhin, Krot, Shilov, and Pikaev during their visit to the Savannah River Technical Center on March 29, 1996. 
- $\quad$ Karraker, D. G., "Plutonium(VI) Solubility Studies in Savannah River Site High-Level Waste Supernate," WSRC-TR-95-0244, Savannah River Technology Center, Aiken, South Carolina (1995).

- Karraker, D. G., "Studies on SRS Waste Tank Supernate Solutions," WSRC-TR-96-407.1, Savannah River Technology Center, Aiken, South Carolina (1996).

\subsection{VISIT OF IPC/RAS SCIENTISTS TO THE UNITED STATES}

Technical information on the Hanford Site, Savannah River Site, and Oak Ridge National Laboratory tank wastes was given to Professors Peretrukhin, Krot, Shilov, and Pikaev of the IPC/RAS during their liaison-funded visit to the United States in March and April 1996.

Technical information on the DOE Site tank waste systems and tank chemistries was obtained at the "Tank Waste Chemistry" symposium sponsored by the Industrial and Engineering Division of the American Chemical Society (ACS) at the ACS $211^{\text {th }}$ national meeting, March 24 to 28, 1996. The scientists met a number of DOE and DOE contractor technical personnel during this meeting, attended the 26 oral presentations, and viewed the 19 poster presentations.

The scientists learned of Savannah River Site tank waste properties from Dr. David Hobbs during a meeting at the Savannah River Technical Center (SRTC). Dr. David Karraker, also of SRTC, presented an overview of his studies on the solubility of actinides (uranium, neptunium, and plutonium) in alkaline media simulating the Savannah River Site tank wastes. Unfortunately, a canceled flight decreased the planned day-long visit at the SRTC to four hours. Drs. Hobbs and Karraker graciously extended their Friday work day until well after 9:00 P.M. to host this visit.

The scientists also visited the Hanford Site April 1 to 3, 1996. A road tour of the Site on April 1 was led by Steve Buckingham, a retired chemist with over 40 years experience at Hanford. A visit to the PUREX plant also took place, with presentations by Don Harlow, a highly experienced plant engineer. The day ended with a visit to the 222-S Laboratory given by Dr. Jim Jewett, manager of the Process Chemistry and Statistics group of the Westinghouse Hanford Company. The 222-S Laboratory tour showed the analytical and process development facilities available.

A technical review and discussion of the IPC/RAS program for FY 1995 and 1996 was conducted on April 2 by Dr. Jack Watson, Dr. Kurt Gerdes (Program Coordinator, DOE-HQ), Cal Delegard, and the four IPC/RAS scientists. Subsequent individual discussions with Hanford Site scientists and engineers occurred on April 3. 


\subsection{DIALOGUE ON PLUTONIUM(V) STABILITY AND PROPERTIES IN ALKALINE MEDIA}

A technical dialogue between Dr. Ivan G. Tananaev of the IPC/RAS and Cal Delegard was initiated during Delegard's visit to the IPC/RAS in August 1995, and it continued by a FAX exchange in autumn 1995. At issue, was the chemistry of pentavalent plutonium in alkaline solution. The stability of Pu(V) in alkaline solution was observed by IPC/RAS scientists to be lower than would be expected by simple consideration of the measured $\mathrm{Pu}(\mathrm{V})-\mathrm{Pu}(\mathrm{IV})$ formal potentials in alkali metal $(\mathrm{Li}, \mathrm{Na})$ hydroxide solutions.

The IPC/RAS scientists observed the relative instability of dissolved $\mathrm{Pu}(\mathrm{V})$ in coprecipitation reactions reported by Krot et al. (1996), in oxidation/reduction studies reported by Shilov et al. (1996), and in Pu(V) salt solubility tests reported by Peretrukhin et al. (to be issued). Each report suggested that the instability of $\mathrm{Pu}(\mathrm{V})$, shown by its propensity to convert to $\mathrm{Pu}(\mathrm{IV})$ hydrous oxide of low solubility, was caused by its disproportionation to Pu(IV) and Pu(VI).

On the other hand, electrochemical studies, show $\mathrm{Pu}(\mathrm{V})$ is stable to disproportionation in alkaline media (Bourges 1972; Peretrukhin and Alekseeva 1974; Peretrukhin et al. 1994; and Maslennikov et al. 1993). Furthermore, Bourges (1972) observed that Pu(V) forms by reproportionation when freshly precipitated $\mathrm{Pu}(\mathrm{IV})$ hydrous oxide and dissolved $\mathrm{Pu}(\mathrm{VI})$ are mixed in alkaline solution. Optical absorption spectra attributed to $\mathrm{Pu}(\mathrm{V})$ in alkaline solution also have been gathered (Bourges 1972 and Delegard 1985). These observations on the stability of $\mathrm{Pu}(\mathrm{V})$ in alkaline media have been summarized in a review of the chemistry of actinides in alkaline media (Peretrukhin et al. 1995).

\subsubsection{Observations by Dr. Tananaev}

In an October 25, $1995 \mathrm{FAX}$, Dr. Tananaev cited a number of observations leading him to believe that $\mathrm{Pu}(\mathrm{V})$ is unstable in alkaline media:

- Plutonium concentrations increase with increasing hydroxide concentration both in the presence and in the absence of reductants; therefore, $\mathrm{Pu}(\mathrm{IV})$ oxidative dissolution (to form $\mathrm{Pu}(\mathrm{V})$ dissolved species) is not required to explain the apparent increased "solubility" of $\mathrm{PuO}_{2} \times \mathrm{xH}_{2} \mathrm{O}$.

- Neptunium(V) and (VI), americium(V) and (VI), and plutonium(VI) give spectra whose peak intensities decrease about 20-fold and whose locations shift about $30 \mathrm{~nm}$ towards higher wavelengths in changing from $0.1 \mathrm{M} \mathrm{HClO}_{4}$ solution to $1 \mathrm{M}$ alkali. These decreases in optical absorption at high hydroxide concentrations have been attributed to the formation of centrosymmetric 
octahedral pentavalent or hexavalent species of the form $\mathrm{AnO}_{2}(\mathrm{OH})_{4}^{3-, 2-}$, respectively (refer to Tananaev 1989, 1990, and 1994). ${ }^{1}$

In alkaline solution, the analogous $\mathrm{Pu}(\mathrm{V})$ hydroxide complex should have peak absorption near $610 \mathrm{~nm}$ with a molar extinction coefficient, $\epsilon$, of less than 1 $\mathrm{M}^{-1} \mathrm{~cm}^{-1}$ based on the $575 \mathrm{~nm}$ band $\left(\epsilon\right.$ of $\left.20 \mathrm{M}^{-1} \mathrm{~cm}^{-1}\right)$ for $\mathrm{Pu}(\mathrm{V})$ in acid solution. For this reason, the spectra attributed to $\mathrm{Pu}(\mathrm{V})$ published by Bourges (1972) and Delegard (1985), with numerous sharp absorption lines having molar extinction coefficients of 5 to $13 \mathrm{M}^{-1} \mathrm{~cm}^{-1}$, cannot be caused by the purported $\mathrm{Pu}(\mathrm{V})$. Instead, the peaks may be attributed to a mixture of Pu(IV) and Pu(VI) species.

- The redox potential of $\mathrm{Pu}(\mathrm{IV}) /(\mathrm{V})$ in alkali may be calculated based on the potential in acid and the solubility products of the formed Pu(IV) oxide and $\mathrm{Pu}(\mathrm{V})$ hydroxide. The calculated $\mathrm{Pu}(\mathrm{IV}) /(\mathrm{V})$ potential is about 0.6 volts and indicates $\mathrm{Pu}(\mathrm{V})$ would disproportionate. (In contrast, the potential measured by Peretrukhin and colleagues is about -0.6 volts.)

- The Np(IV)/(V) couple proposed by Peretrukhin and Spitsyn (1982), -0.95 volts, is too low based on reproportionation equilibrium constants determined by Professor Shilov in unpublished work. Using the reproportionation measurements, the potential should be about 0.113 volts. The analogous plutonium potential should be similar.

- The potential of the Pu(IV)/(V) potential is about 0.4 volts in carbonate media. The $\mathrm{Pu}(\mathrm{IV}) /(\mathrm{V})$ potential in hydroxide media should be similar to this value.

- Addition of stoichiometric amounts of hydrazine (or substoichiometric amounts in the presence of low hydroxide concentrations) to preparations of $\mathrm{Na}_{2} \mathrm{PuO}_{2}(\mathrm{OH})_{3} \cdot \mathrm{xH}_{2} \mathrm{O}$ gives acid-insoluble green compounds having solubilities in alkali of about $10^{-6}$ to $10^{-7} \mathrm{M}$. These results indicate $\mathrm{Pu}(\mathrm{IV})$ solids form readily by reduction of $\mathrm{Pu}(\mathrm{V})$ salts by hydrazine, even with insufficient amounts of hydrazine.

\footnotetext{
${ }^{1}$ The sharp $f-f$ electronic transitions in actinides and lanthanides normally are forbidden by (Laporte) symmetry arguments and thus are weak if they exist at all. Asymmetries introduced to the f-electron shell by imposition of an asymmetric ligand field cause a relaxation of these rules and leads to the sharp optical absorptions observed in lanthanide and actinide spectra. The decreasing absorptions of the $\mathrm{Np}(\mathrm{V}$ and $\mathrm{VI})$, $\mathrm{Am}$ (V and VI), and Pu(VI) hydroxide complexes, as hydroxide concentration increase, are evidence of formation of centrosymmetric ligand fields. The symmetry is attributed to tetrahydroxide actinyl complexes in which the hydroxide ligands are arranged equatorially and symmetrically around the linear central actinyl ion.
} 


\subsubsection{Reply}

A reply to Dr. Tananaev's observations was made in a November 9, 1995 FAX. The FAX pointed out that the reactions measured by Peretrukhin and colleagues for the reduction of $\mathrm{Pu}(\mathrm{V})$ to $\mathrm{Pu}(\mathrm{IV})$ were irreversible and proceeded to very freshly formed $\mathrm{Pu}(\mathrm{IV})$. The $\mathrm{Pu}(\mathrm{IV})$ then rapidly precipitated on the electrode (as reported). The formed solids then could undergo olation (oxygen bridging) and crystallization reactions. With increasing time and crystallization, the potential for the reverse oxidation reaction, $\mathrm{Pu}^{(\mathrm{M})} \mathrm{O}_{2} \cdot \mathrm{xH}_{2} \mathrm{O} \rightarrow \mathrm{Pu}(\mathrm{V})$, would become increasingly positive and would be well above the potential of the purely aqueous phase $\mathrm{Pu}(\mathrm{V}) \rightarrow \mathrm{Pu}(\mathrm{IV})$ reaction measured by Peretrukhin and colleagues. In other words, because of the precipitation (and the stability) of the $\mathrm{Pu}(\mathrm{IV})$ solid phase, the electrochemical measurements of Peretrukhin and colleagues cannot, by themselves, reflect the extent of oxidative dissolution of $\mathrm{Pu}(\mathrm{IV})$ hydrous oxide to form $\mathrm{Pu}(\mathrm{V})$ solution species.

It was also noted that unless the $\mathrm{PuO}_{2}(\mathrm{am}) / \mathrm{Pu}(\mathrm{V})$ potential increases above the $\mathrm{Pu}(\mathrm{V}) / \mathrm{Pu}(\mathrm{VI})$ potential (given as 0.21 volts in $1 \mathrm{M} \mathrm{NaOH}$ [Peretrukhin and Spitsyn 1982]), disproportionation cannot occur.

Further evidence of $\mathrm{Pu}(\mathrm{IV})$ hydrous oxide oxidative dissolution to form $\mathrm{Pu}(\mathrm{V})$ dissolved species can be derived by interpretation of published measurement data (Delegard 1985). These data and their interpretation were presented in the November 9, 1995 FAX and are summarized here.

The data involve plutonium concentration and electrode potential measurements made in mixed $\mathrm{NaOH} / \mathrm{NaNO}_{2}$ aqueous solutions. These measurements were compared with analogous plutonium concentration and potential measurements made in the $\mathrm{NaOH}$ aqueous system and for which equations relating plutonium concentration and electrode potential to $\mathrm{NaOH}$ chemical activity were derived.

The relevant electrode potential and plutonium concentration data, as well as prediction equations, are given in Table 4-1. For example, in $4 \mathrm{M} \mathrm{NaOH} / 4 \mathrm{M} \mathrm{NaNO}_{2}$, the measured potential was -0.014 volts. At that same $\mathrm{NaOH}$ activity $\left(\mathrm{a}_{\mathrm{NaOH}}\right), 6.76$ molal, the potential in $\mathrm{NaOH}$ aqueous solution is predicted to be 0.002 volts. The -0.016 volt difference indicates that the mixed $\mathrm{NaOH} / \mathrm{NaNO}_{2}$ solution was chemically reducing compared with the $\mathrm{NaOH}$ solution at the same $\mathrm{NaOH}$ chemical activity. 
Table 4-1. Predicted and Measured Electrode Potentials and Plutonium Concentrations in $\mathrm{NaOH} / \mathrm{NaNO}_{2}$ Solutions.

\begin{tabular}{|c|c|c|c|c|c|c|c|c|}
\hline Kof & 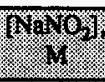 & 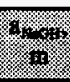 & Fiv & $\sqrt{6}$ & E. & $\begin{array}{l}\log f_{i} \\
n\end{array}$ & 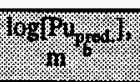 & 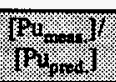 \\
\hline 4.00 & 4.00 & 6.76 & -0.014 & 0.002 & -0.016 & -6.326 & -5.617 & 0.195 \\
\hline 5.00 & 1.00 & 6.56 & -0.003 & 0.003 & -0.006 & -5.907 & -5.644 & 0.545 \\
\hline 5.00 & 1.50 & 7.24 & -0.006 & -0.001 & -0.005 & -5.999 & -5.556 & 0.361 \\
\hline 5.00 & 2.00 & 7.69 & -0.018 & -0.004 & -0.014 & -6.216 & -5.503 & 0.194 \\
\hline 5.00 & 3.00 & 9.32 & -0.046 & -0.013 & -0.033 & -6.097 & -5.332 & 0.172 \\
\hline 5.00 & 3.00 & 9.32 & -0.036 & -0.013 & -0.023 & -5.893 & -5.332 & 0.275 \\
\hline 5.00 & 4.00 & 11.37 & -0.055 & -0.022 & -0.033 & -6.032 & -5.156 & 0.133 \\
\hline 6.00 & 2.00 & 12.32 & -0.036 & -0.025 & -0.011 & -5.207 & -5.085 & 0.755 \\
\hline 7.00 & 1.00 & 15.82 & -0.052 & -0.037 & -0.015 & -5.253 & -4.864 & 0.408 \\
\hline
\end{tabular}

Notes:

- $p e=16.9 E_{\text {pred. }}=-1.75 \log a_{\text {N.OH }}+1.48$; equation (3), Delegard (1985); $E_{\text {prod. }}=-0.1036 \log a_{\mathrm{NaOH}}+0.0876$.

b $\log \left[\mathrm{Pu}_{\text {prod. }}\right]=2.04 \log \mathrm{a}_{\mathrm{N} \approx \mathrm{OH}}-7.31$; equation (1), Delegard (1985).

Similarly, for the $4 \mathrm{M} \mathrm{NaOH} / 4 \mathrm{M} \mathrm{NaNO}_{2}$ solution, the measured plutonium solution concentration was $10^{-6.326}\left(4.72 \times 10^{-7}\right)$ molal, about $20 \%$ of the $10^{-5.617}\left(2.42 \times 10^{-6}\right)$ molal concentration predicted in $\mathrm{NaOH}$ solution at the same $\mathrm{NaOH}$ chemical activity. As argued previously (Delegard 1985), the chemically reducing conditions imposed by $\mathrm{NaNO}_{2}$ appeared to inhibit the oxidative dissolution of $\mathrm{Pu}^{(\mathrm{IV})} \mathrm{O}_{2} \cdot \mathrm{xH}_{2} \mathrm{O}$.

Graphical interpretation of the data given in Table 4-1 may be performed to correlate the decrease in plutonium solution concentration with the decrease in electrode potential. As shown in the following arguments, the logarithm of the ratio of plutonium solution concentrations in the mixed $\mathrm{NaOH} / \mathrm{NaNO}_{2}$ and $\mathrm{NaOH}$ systems, divided by the difference in the electrode potentials, is proportional to the number of electrons participating in the proposed oxidative dissolution of the observed Pu(IV) hydrous oxide solid phase:

$$
\mathrm{y} \mathrm{OH}^{-}+\mathrm{PuO}_{2}(\mathrm{~s}) \rightleftharpoons \mathrm{PuO}_{2}(\mathrm{OH})_{y}^{(\mathrm{y}-\mathrm{n})-}+\mathrm{ne}^{-} .
$$


The following equilibrium equation represents the oxidative dissolution reaction:

$$
K=\frac{[\mathrm{Pu}]\left(\mathrm{e}^{-}\right)^{\mathrm{D}}}{\left(\mathrm{OH}^{-}\right)^{y}}
$$

In equation (1), $\mathrm{K}$ is the equilibrium constant, [Pu] represents the molal concentration of the plutonium complex, $\left(\mathrm{e}^{-}\right)$is the electron activity, $\mathrm{n}$ is the number of electrons involved in the oxidation reaction, $\left(\mathrm{OH}^{-}\right)$is the hydroxide ion activity, and $y$ is the number of hydroxide ions involved in formation of the dissolved plutonium complex.

At a fixed hydroxide ion activity (taken to be proportional to the sodium hydroxide activity), equation (1) may be simplified:

$$
K^{*}=[P u]\left(e^{-}\right)^{n}
$$

where $\mathrm{K}^{*}$ is a conditional equilibrium constant incorporating the hydroxide activity term. Thus, at equal hydroxide activities, this equation holds for both the $\mathrm{NaOH}$ aqueous system and the $\mathrm{NaOH} / \mathrm{NaNO}_{2}$ aqueous system since only electron activities and plutonium concentrations are involved. Therefore:

$$
K^{\bullet}=[\mathrm{Pu}]\left(\mathrm{e}^{-}\right)^{\mathrm{n}}=[\mathrm{Pu}]^{\prime}\left(\mathrm{e}^{-}\right)^{\prime \mathbf{n}}
$$

where the prime (') marks indicate the $\mathrm{NaOH} / \mathrm{NaNO}_{2}$ system. Equation (3) may be rearranged:

$$
\frac{[\mathrm{Pu}]^{\prime}}{[\mathrm{Pu}]}=\frac{\left(\mathrm{e}^{-}\right)^{\mathrm{n}}}{\left(\mathrm{e}^{-}\right)^{\prime \mathbf{n}}}
$$

or, taking logarithms:

$$
\log \frac{[\mathrm{Pu}]^{\prime}}{[\mathrm{Pu}]}=\mathrm{n} \log \frac{\left(\mathrm{e}^{-}\right)}{\left(\mathrm{e}^{-}\right)^{\prime}}=\mathrm{n}\left[\log \left(\mathrm{e}^{-}\right)-\log \left(\mathrm{e}^{-}\right)^{\prime}\right]
$$

The logarithm of the electron activity is related to the electrode potential by the equation:

$$
\log \left(e^{-}\right)=\frac{-E}{0.059 .16}
$$


Equation (6) may be used to reformulate equation (5) as follows:

$$
\log \frac{[\mathrm{Pu}]^{\prime}}{[\mathrm{Pu}]}=n\left[\log \left(\mathrm{e}^{-}\right)-\log \left(\mathrm{e}^{-}\right)^{\prime}\right]=\frac{\mathrm{n}}{0.05916}\left(\mathrm{E}^{\prime}-\mathrm{E}\right)
$$

where $\mathrm{E}$ and $\mathrm{E}^{\prime}$ are the electrode potentials in the $\mathrm{NaOH}$ and $\mathrm{NaOH} / \mathrm{NaNO}_{2}$ systems, respectively, at a given sodium hydroxide activity. In terms of the values given in Table 4-1 for the measured $\left(\mathrm{NaOH} / \mathrm{NaNO}_{2}\right)$ and predicted $(\mathrm{NaOH})$ plutonium concentrations and electrode potentials, equation (7) becomes:

$$
\log \frac{\left[\mathrm{Pu}_{\text {mas. }}\right]}{\left[\mathrm{Pu}_{\text {pred. }}\right]}=\frac{\mathrm{n}}{0.05916}\left(\mathrm{E}_{\text {mess. }}-\mathrm{E}_{\text {pred. }}\right)
$$

Therefore, plotting the logarithm of the ratio of the plutonium concentrations (measured in the $\mathrm{NaOH} / \mathrm{NaNO}_{2}$ system and predicted from the $\mathrm{NaOH}$ system at the same sodium hydroxide activity) versus the difference of the measured $\left(\mathrm{NaOH} / \mathrm{NaNO}_{2}\right)$ and predicted $(\mathrm{NaOH})$ electrode potentials gives a slope of $\mathrm{n}$, the number of electrons involved in the oxidative dissolution of $\mathrm{PuO}_{2} \cdot \mathrm{xH}_{2} \mathrm{O}$, divided by 0.05916 .

The plot of these plutonium concentration and electrode potential values (see Table 4-1) is presented according to equation (8) in Figure 4-1.

Figure 4-1. Plutonium Hydrous Oxide Solubility Dependence on Electrode Potential in $\mathrm{NaOH} / \mathrm{NaNO}_{2}$ Solutions

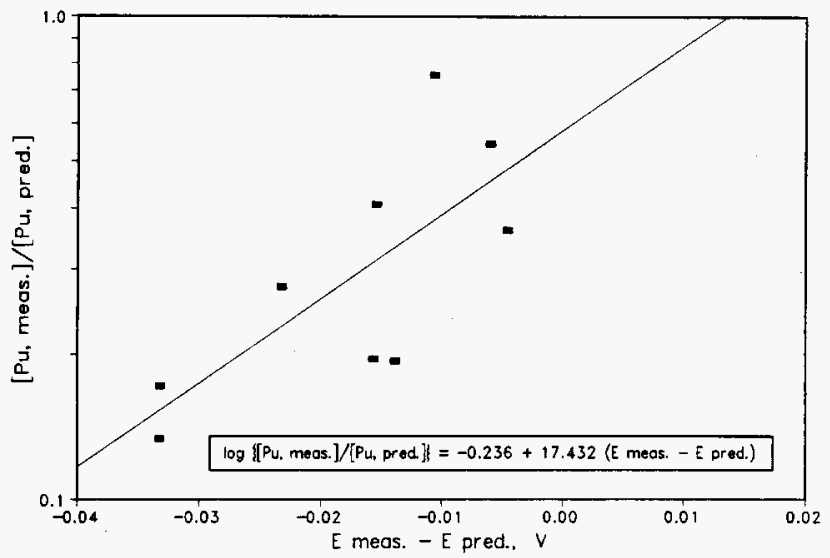


The best-fit linear regression of the data is displayed as a straight line through the data points. The line follows the equation:

$$
\log \frac{\left[\mathrm{Pu}_{\text {meses }}\right]}{\left[\mathrm{Pu}_{\mathrm{pred} .}\right]}=-0.236+17.432\left(\mathrm{E}_{\text {mees }}-\mathrm{E}_{\text {prod }}\right)
$$

The slope is 17.4 ( \pm 6.1 ). Thus, the number of electrons, $n$, involved in the oxidative dissolution is:

$$
n=0.05916 \times 17.4( \pm 6.1)=1.03( \pm 0.36) \cong 1
$$

This analysis therefore supports the original contention (Delegard 1985) that the dissolution of $\mathrm{PuO}_{2} \cdot \mathrm{xH}_{2} \mathrm{O}$ in highly alkaline media proceeds by a one-electron oxidation to form $\mathrm{Pu}(\mathrm{V})$ dissolved species.

\subsection{PROVISION OF A LIQUID SCINTILLATION COUNTER AND ULTRAFILTERS TO THE IPC/RAS}

A liquid scintillation counter (LSC) was selected, procured, and delivered to the IPC/RAS. The LSC was procured to detect and quantify, separately and simultaneously, the concentrations of beta- and alpha-emitting radionuclides (for example, ${ }^{99} \mathrm{Tc}$, and ${ }^{237} \mathrm{~Np},{ }^{239} \mathrm{Pu}$, and ${ }^{241} \mathrm{Am}$, respectively).

With an LSC, more accurate analytical results and lower detection limits could be obtained for the DOE-funded studies. Without the LSC, cumbersome and error-inducing steps (neutralization, carrier precipitation, and acid dissolution) are required prior to preparation of classic planchet mounts. These steps are required to separate actinides and technetium from the high sodium salt matrices implicit in Hanford Site tank waste experiments. With an LSC, no separations are required prior to simple introduction of aliquots of the test solutions into the scintillation cocktail for counting in the LSC. The LSC also has a higher sensitivity which reduces the detection limit. Enhanced sensitivity is especially important for studies of

${ }^{99} \mathrm{Tc}$ and ${ }^{237} \mathrm{~Np}$ which have low specific activities.

A market survey of suitable LSC instruments was conducted. The following criteria were considered in choosing the LSC:

- Simultaneous quantitation of alpha and beta radionuclides

- Instrument operation on $220 \mathrm{~V} / 50 \mathrm{~Hz}$ mains power supply

- Instrument delivery and installation at the IPC/RAS 
- Training on use of the instrument in Russia; preferably in Moscow

- Established vendor sales and service office in Russia; preferably in Moscow.

Three candidate LSC devices met the stated criteria: the Model 1415-001 DSA ${ }^{\text {m }}$ by Wallac $\mathrm{Oy}^{2}$ (about \$52,000), the LSA Model 2700TR ${ }^{\mathrm{N}}$ by Packard ${ }^{3}$ (about $\$ 52,000$ ), and the LS6500 LL ${ }^{\text {TM }}$ by Beckman ${ }^{4}$ (about $\$ 32,000$ ). Wallac Oy also offered a more sensitive instrument at about $\$ 80,000$.

The performance characteristics of the candidate LSCs were assessed. The figure of merit in determining LSC performance is the counting efficiency squared divided by the associated background count rate. All instruments had equivalent figures of merit. The deciding factor then became price; on this basis, the Beckman LSC was selected. The Beckman LSC was delivered and installed at the IPC/RAS in February 1996. It is functioning well according to IPC/RAS scientists.

Ultrafilters also were supplied to the IPC/RAS in solid-liquid separations in solubility and other tests. Model CF25 ultrafilters, manufactured by Amicon ${ }^{5}$, were provided. These filters have a nominal $1.8 \mathrm{~nm}$ pore size.

${ }^{2} 1415-001$ DSA is a trademark of Wallac Oy, Turku, Finland, and associated with EG\&G Company, Gaithersburg, Maryland.

${ }^{3}$ LSA Model 2700TR is a trademark of Packard, a Canberra Company, Meriden, Connecticut.

${ }^{4}$ LS6500LL is a trademark of Beckman Instruments, Brea, Califomia.

${ }^{s}$ CF25 is a trademark of Amicon, Inc., ef-Beverly, Massachusetts. 


\subsection{DISSEMINATION SUBTASK}

The dissemination subtask included presentation of IPC/RAS findings to technical personnel in the DOE community and publication of IPC/RAS reports as Westinghouse Hanford Company documents.

\subsection{TECHNICAL PRESENTATIONS}

Technical presentations on the IPC/RAS FY 1995 tasks were made by the IPC/RAS scientists in scientific colloquia at the American Chemical Society (ACS) national meeting, the Savannah River Technical Center, and at the Hanford Site. The IPC/RAS liaison task supported the travel and living expenses of the four scientists to the United States.

The 211 ${ }^{\text {th }}$ National Meeting of the ACS took place March 24 to 28, 1996 in New Orleans, Louisiana. The following IPC/RAS papers were presented at the ACS Division of Industrial and Engineering Chemistry symposium, "Tank Waste Chemistry:"

- "Study of Some Redox Reactions of Neptunium and Plutonium for the Stabilization of Particular Oxidations States in Alkaline Media" by

V. P. Shilov, N. N. Krot, A. Yusov, A. Garnov, and V. Perminov

- "Gamma Radiolysis of Alkaline Aqueous Solutions of Neptunium and Plutonium" by A. K. Pikaev and A. V. Gogolev

- $\quad$ "Coprecipitation of Np(VI,V) and Pu(VI,V) from Alkaline Solutions with Some Carriers Formed by the Method of Appearing Reagents" by N. N. Krot, V. P. Shilov, A. Bessonov, N. Budantseva, I. Charushnikova, and

V. Perminov.

- "Solubility of Transuranium Elements and Technetium Hydroxide Compounds in $\mathrm{NaOH}$ Solutions in the Presence of Redox and Complexing Agents" V. F. Peretroukhin, I. G. Tananaev, S. V. Kryutchkov, V. I. Silin, and C. H. Delegard (Peretroukhin et al. 1995)

All papers were presented orally except the radiolysis report which was presented as a poster. In addition, "Calcination/Dissolution Treatment of Hanford Site Tank Waste" by C. H. Delegard (1996), which reported work supported by ESP in previous years, was presented orally.

The four IPC/RAS scientists presented their papers in a roundtable session at the Savannah River Technical Center (SRTC) on March 29, 1996. Dr. David Hobbs, Dr. David Karraker, and two other SRTC persons attended. 
Finally, the four IPC/RAS scientists presented their work in a sitewide "Hanford Technical Exchange" on April 2, 1996. The following talks also were given at the Exchange:

- "Scientific Activity of the Institute of Physical Chemistry," by A. K. Pikaev of the IPC/RAS

- "Thermodynamic Modeling of the Solubility of $\mathrm{PuO}_{2} \cdot \mathrm{xH}_{2} \mathrm{O}(\mathrm{am})$ in Alkaline Hanford Waste Solutions," by Linfeng Rao of the Pacific Northwest National Laboratory

- "The Solubility and Aqueous Thermodynamics of Tetravalent Actinides in Concentrated Carbonate Solutions," by Andrew Felmy of the Pacific Northwest National Laboratory.

\subsection{TECHNICAL PUBLICATIONS}

Reports on the work performed by the IPC/RAS in FY 1995 were prepared and issued, without editing, to a limited distribution of $\mathrm{DOE}$ and contractor personnel by Thomas $\mathrm{E}$. Albert and Associates in the autumn/winter of 1995 and spring of 1996 . As part of the liaison task, these reports are being technically reviewed, formatted, edited, and issued (after rechecking by the authors) as publically-available Westinghouse Hanford Company documents.

To date, the following reports have been issued:

- $\quad$ Investigation of Some Redox Reactions of Neptunium, Plutonium, Americium, and Technetium in Alkaline Media" (Shilov et al. 1996)

- $\quad$ "Investigation on the Coprecipitation of Transuranium Elements from Alkaline Solutions by the Method of Appearing Reagents" (Krot et al. 1996).

Two other reports are in an advanced stage of editing:

- "Radiolysis of Actinides and Technetium in Alkaline Media" (Pikaev et al. to be issued)

- "Determination of the Solubility of Np(IV-VI), Pu(III-VI), Am(III-VI), and Tc(IV,V) Hydroxo Compounds in 0.5 to $14 \mathrm{M} \mathrm{NaOH}$ Solutions" (Peretrukhin et al. to be issued). 


\subsection{PATENT}

A potentially patentable invention was discovered by Professor Nikolai N. Krot and his colleague, Dr. Iraida A. Charushnikova, in their work on the coprecipitation task. The invention has been described in an Application for United States Letters Patent, number S-86-247 titled, "Removal of Dissolved Actinides from Alkaline Solutions by the Method of Appearing Reagents." The Application was prepared by Mr. Harry Levi of Emrich and Dithmar, 300 South Wacker Drive, Chicago, Illinois. The firm was engaged by Ms. Rebecca Keen of SAIC, 555 Quince Orchard Road, Suite 500, Gaithersburg, Maryland. The liaison provided assistance in the preparation of the technical details of the Application. 
WHC-SP-1184

This page intentionally left blank. 


\subsection{VERIFICATION SUBTASK}

Verifications of the findings obtained by the IPC/RAS scientists in their FY 1995 redox reagent/reaction, solubility, coprecipitation, and radiation chemistry tasks were undertaken by comparing their results with published results from independent laboratories and with previously unpublished results obtained in the author's laboratory. The results of these comparisons are presented in this section. Investigating the attainment of equilibrium in tests involving the slowly crystallizing $\mathrm{Pu}(\mathrm{IV})$ hydrous oxide phase also was a part of this task.

\subsection{ATTAINING EQUILIBRIUM}

Attaining equilibrium in plutonium(IV) hydrous oxide solubility tests in strongly alkaline solution is difficult, if not impossible. Previous studies have shown equilibrium, or even steady-state plutonium concentrations, are not obtained even after almost three-years aging (Delegard 1985). The following data, obtained by precipitating Pu(IV) (introduced as acidic nitrate solution) in $5 \mathrm{M} \mathrm{NaOH}$ solution, support this conclusion. Results from three separate solubility experiments were consistent; plutonium concentrations rose about a factor of 10 in aging from one hour to one week, then decreased a factor of 10 in further aging to almost three years (see Figure 6-1).

Figure 6-1. Solubility Variation with Aging of $\mathrm{PuO}_{2} \cdot \mathrm{xH}_{2} \mathrm{O}$ in $5 \mathrm{M} \mathrm{NaOH}$

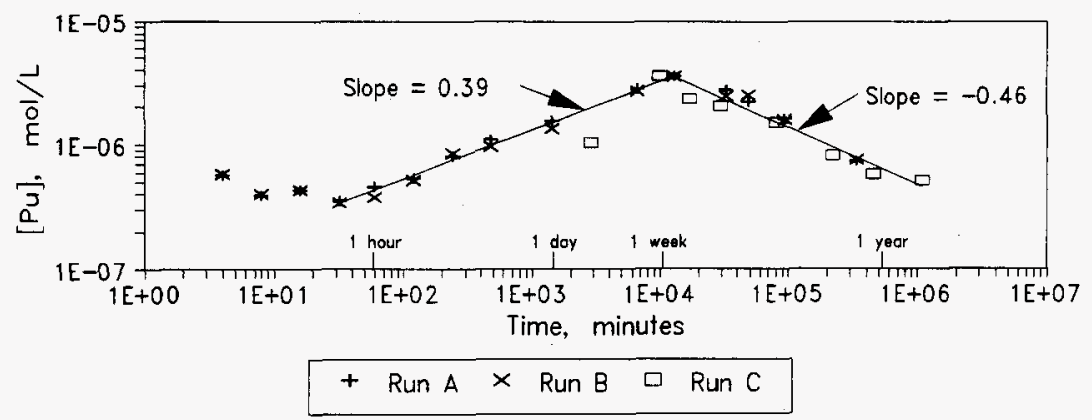

These results indicate that, at least for Pu(IV) hydrous oxide, establishing "equilibrium" does not occur in short-term experiments. Therefore, care must be taken in analyzing or interpreting solubility investigations or in any tests in which $\mathrm{Pu}(\mathrm{IV})$ hydrous oxide participates. 


\subsection{SOLUBILITY}

The solubilities of the actinides $(\mathrm{Np}, \mathrm{Pu}$, and $\mathrm{Am})$ and technetium in various oxidation states over a range of sodium hydroxide concentrations were investigated by Peretrukhin et al. (to be issued). Results from the solubility studies for the actinides may be compared with results obtained in other laboratories using similar solution compositions.

\subsubsection{Neptunium(V)}

The solubility of sodium neptunate( $\mathrm{V}$ ) salts in varying concentrations of $\mathrm{NaOH}$ was reported (Peretrukhin et al. to be issued). The solution concentrations obtained by the IPC/RAS for analogous plutonium and americium systems are similar (except for plutonium at low $\mathrm{NaOH}$ concentrations) and indicate similar solid phases and solution species. The IPC/RAS results can be compared with data recently published (Karraker 1994b and Delegard 1995a) as shown in Figure 6-2.

Figure 6-2. Solubility of $\mathrm{Np}(\mathrm{V})$ Salts in $\mathrm{NaOH}$ Solutions

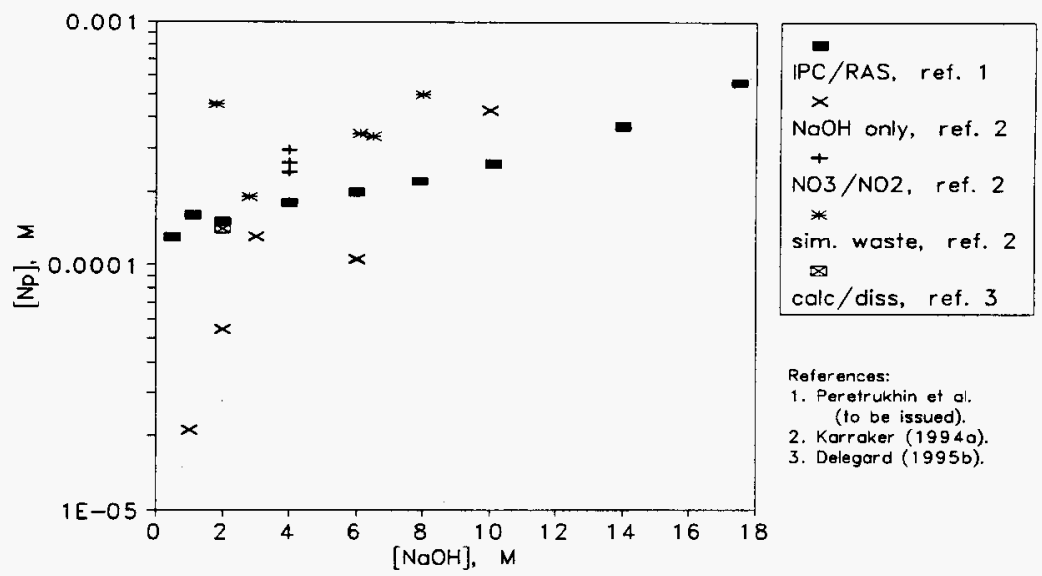

In the IPC/RAS tests, the neptunium concentrations rise smoothly about a factor of five by increasing $\mathrm{NaOH}$ concentrations from 0.5 to $17.5 \mathrm{M}$. Studies by Karraker (1994b) on neptunium(V) salt solubility in simple $\mathrm{NaOH}$ solutions, in $\mathrm{NaOH}$ solutions containing $\mathrm{NaNO}_{3}$ and $\mathrm{NaNO}_{2}$, and in Savannah River Site simulant waste solutions during evaporative concentration, are generally within a factor of two of the values found by the IPC/RAS 
scientists. Karraker (1994b) also reported that $\mathrm{Np}(\mathrm{IV})$ and $\mathrm{Np}(\mathrm{VI})$ converted to $\mathrm{Np}(\mathrm{V})$ in a few days in the synthetic waste solutions studied; that is, $N p(V)$ seems to be the stable oxidation state in aerated strongly alkaline solution.

The single data point from Delegard (1995) reflects $\mathrm{Np}(\mathrm{V})$ concentrations found in a solution prepared from calcination and water dissolution of a neptunium-spiked Hanford Site simulant waste. The solution species was identified as $\mathrm{Np}(\mathrm{V})$ by absorption spectrophotometry. The $\mathrm{Np}(\mathrm{V})$ solution concentration found in the single test was very near the concentration expected from the IPC/RAS studies.

\subsubsection{Plutonium(IV)}

The solubility of plutonium(IV) hydrous oxide in the presence of $0.1 \mathrm{M}$ hydrazine holding reductant was determined by the IPC/RAS after 72 hours equilibration time (Peretrukhin et al. to be issued). Confirmation that the solution phase plutonium was tetravalent was not performed because conventional spectrophotometry is almost impossible at the low concentrations involved, and because valence tests on the acid side would be compromised by the residual hydrazine.

Previously unpublished studies performed by the author were conducted at similar conditions ( $0.05 \mathrm{M}$ hydrazine and 48 hours contact time). The data from these two studies are compared in Figure 6-3. The two sets of data agree well over the entire $\mathrm{NaOH}$ concentration range except for one pair of data points above $14 \mathrm{M} \mathrm{NaOH}$. In that case, the $0.05 \mathrm{M}$ hydrazine in the author's studies may have been depleted, allowing the plutonium(IV) solids to air-oxidize and dissolve as $\mathrm{Pu}(\mathrm{V})$.

The plutonium concentrations observed in aerated $\mathrm{NaOH}$ solutions in the absence of hydrazine after two days contact are also shown in Figure 6-3. The difference between plutonium concentrations in the presence and absence of hydrazine is negligible below about $6 \mathrm{M} \mathrm{NaOH}$. Above $6 \mathrm{M} \mathrm{NaOH}$, hydrazine decreases plutonium concentration, presumably by preventing plutonium(IV) hydrous oxide from oxidizing and dissolving.

In light of the postulated $\mathrm{Pu}(\mathrm{IV}) \rightarrow \mathrm{Pu}(\mathrm{V})$ oxidative dissolution reaction, the absence of an effect for hydrazine is unexpected. This observation could be taken as evidence that oxidative dissolution does not occur at lower hydroxide concentrations; that is, the plutonium dissolved species is $\mathrm{Pu}(\mathrm{IV})$ below $6 \mathrm{M} \mathrm{NaOH}$. Hydrazine has been observed to reduce $\mathrm{Pu}(\mathrm{V})$ in alkaline media effectively at lower $(<6 \mathrm{M})$ alkali concentrations (Shilov et al. 1996). These observations are consistent with those of Dr. Tananaev who found that $\mathrm{Pu}(\mathrm{V})$ is reduced readily by hydrazine to form green precipitates ${ }^{6}$ leaving $10^{-6}$ to $10^{-7} \mathrm{M}$ dissolved plutonium (see Section 4.4.1). Further work on this question clearly is warranted and will occur in FY 1996 studies on Pu(V) stability in alkaline media.

\footnotetext{
${ }^{6}$ Plutonium(IV) hydrous oxide is green; Pu(V) sodium salts are grey (Peretrukhin et al. to be issued).
} 
Figure 6-3. Solubility of $\mathrm{Pu}(\mathrm{IV}) \mathrm{Hydrous}$ Oxide in $\mathrm{NaOH}$ Solutions

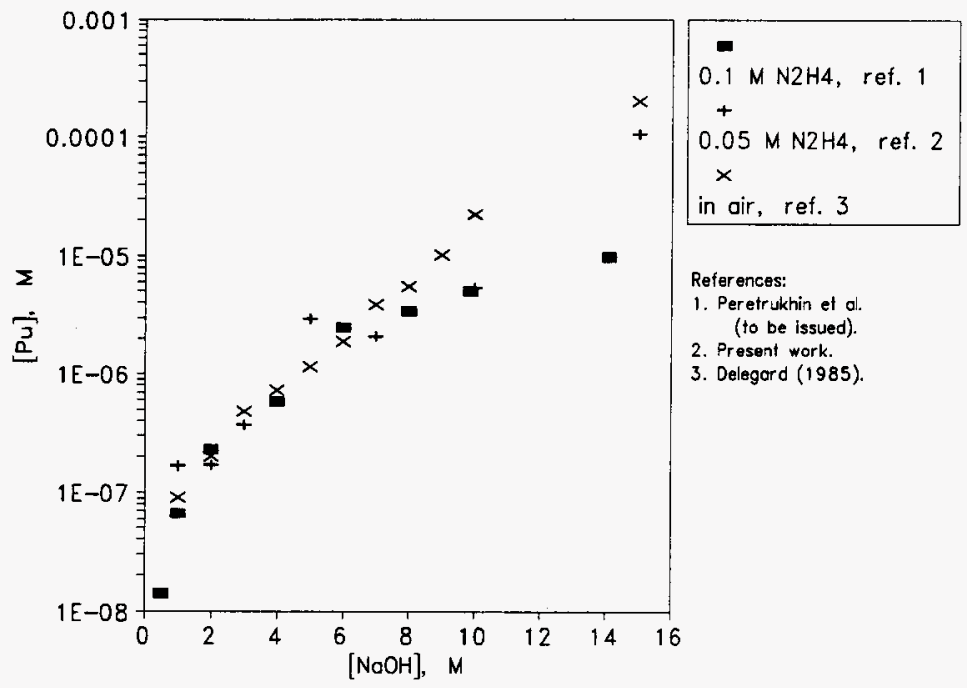

\subsubsection{Plutonium(V)}

The solubility of $\mathrm{Pu}(\mathrm{V})$ sodium salts in solutions ranging from 0.6 to $14 \mathrm{M} \mathrm{NaOH}$ was studied by Peretrukhin et al. (to be issued) and is shown in Figure 6-4. The observed plutonium concentrations increased about seven-fold over this range and were slightly lower than observed for neptunium(V) under comparable conditions above about $6 \mathrm{M} \mathrm{NaOH}$. Below $6 \mathrm{M} \mathrm{NaOH}$, the plutonium concentrations are as much as two-fold lower than those observed for $\mathrm{Np}(\mathrm{V})$. The IPC/RAS scientists ascribed this behavior to the disproportionation and the instability of the sodium plutonate(V) salt.

Two independent data points provisionally support the $\mathrm{Pu}(\mathrm{V})$ solubility results. Both points were observed in calcined and dissolved (C/D) Hanford Site tank waste. One test used a simulant waste, and the plutonium solution species was identified as $\mathrm{Pu}(\mathrm{V})$ by spectrophotometry; the other test was run under similar calcination/dissolution conditions with a genuine waste from tank 241-SY-101. Spectrophotometric confirmation of the plutonium species was not possible for the genuine tank waste because of intense coloration by manganate. 
Figure 6-4. Solubility of $\mathrm{Pu}(\mathrm{V})$ Salts in $\mathrm{NaOH}$ Solutions

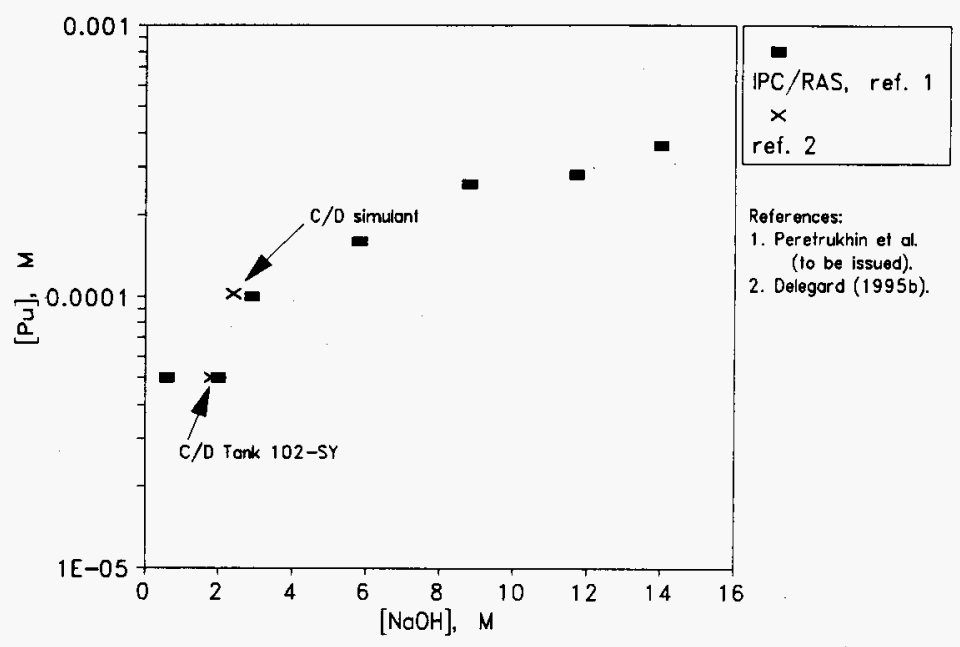

\subsubsection{Plutonium(VI)}

The solubilities of plutonium(VI) sodium salts in $\mathrm{NaOH}$ solutions were not determined explicitly by IPC/RAS studies. However, information was obtained on the solubility of the plutonium compound(s) (presumably sodium salts) formed by oxidation of excess Pu(IV) hydrous oxide by strong oxidants such as persulfate, hypochlorite, and hypobromite (Shilov et al. 1996). Demonstration of the presence of Pu(VI) in the solid phase was shown by change in precipitate color from green (Pu[IV]) to brown (Pu[VI]) and by spectrophotometric analysis of the acid-dissolved solids. The IPC/RAS data are shown in Figure 6-5 and are compared with Pu(VI) solution concentration data reported by Delegard (1985) and by Karraker (1995).

The solubility-limited Pu(VI) solution concentration found in the IPC/RAS studies rises about a factor of 20 as $\mathrm{NaOH}$ concentration increases from 0.4 to $2 \mathrm{M}$. From 2 to $8 \mathrm{M} \mathrm{NaOH}$, the plutonium concentration rises another factor of two. The data from Delegard (1985) in the range 1 to $4 \mathrm{M} \mathrm{NaOH}$ generally follow the IPC/RAS results. The plutonium concentration data of Karraker (1995) are invariant in the $\mathrm{NaOH}$ range tested ( 2 to $10 \mathrm{M} \mathrm{NaOH}$ ) and are markedly lower than the IPC/RAS results. As explained by Karraker (1995), the invariance may be because insufficient plutonium was added; this would also explain the lower apparent solubility observed by Karraker. 
Figure 6-5. Solubility of $\mathrm{Pu}(\mathrm{VI})$ Salts in $\mathrm{NaOH}$ Solutions

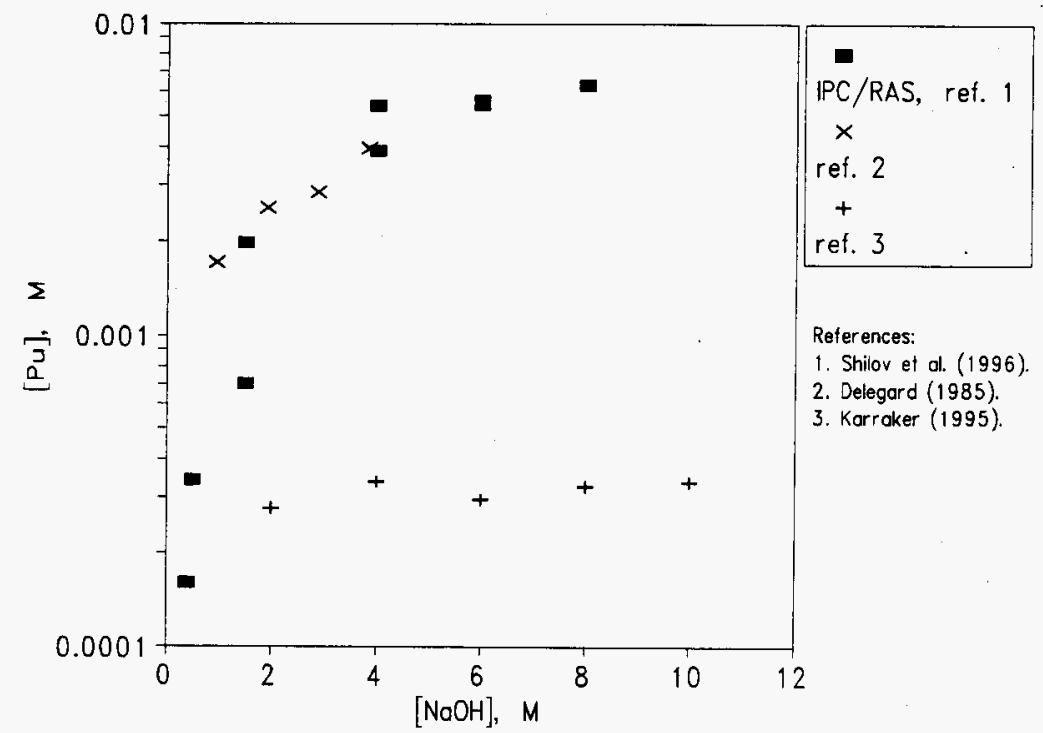

\subsubsection{Plutonium(IV) Carbonate}

The solubility enhancement to $\mathrm{Pu}(\mathrm{IV})$ hydrous oxide in 1 and $4 \mathrm{M} \mathrm{NaOH}$ solution provided by 0.05 and $0.5 \mathrm{M} \mathrm{Na}_{2} \mathrm{CO}_{3}$ was determined (Peretrukhin et al. to be issued). The tests were conducted in the presence of $0.1 \mathrm{M}$ hydrazine. The solubility of $\mathrm{Pu}(\mathrm{IV})$ hydrous oxide in carbonate solutions containing nitrite-holding reductant was determined, and the $2: 1 \mathrm{CO}_{3}^{2-}: \mathrm{Pu}$ complex was postulated to be $\mathrm{Pu}(\mathrm{OH})_{4}\left(\mathrm{CO}_{3}\right)_{2}^{4}$ based on the apparent increase in solubility with an increase in carbonate concentration (Yamaguchi et al. 1994). This interpretation was extended to results published by Delegard (1985) for solutions ranging from 3 to $5 \mathrm{M} \mathrm{NaOH}$ and containing 0.25 to $1 \mathrm{M} \mathrm{Na}_{2} \mathrm{CO}_{3}$. The two data sets were consistent and compatible with the postulated 2:1 carbonate:plutonium complex (Delegard 1995a). The IPC/RAS data are compared with these literature results in Figure 6-6.

The enhancements in plutonium concentrations found by the IPC/RAS agree with those projected from the literature data at $0.5 \mathrm{M} \mathrm{Na}_{2} \mathrm{CO}_{3}$. However, the increases observed at $0.05 \mathrm{M} \mathrm{Na}_{2} \mathrm{CO}_{3}$ are higher than predicted and may be related to insufficient equilibration (contact) time or incomplete phase separation. 
Figure 6-6. Enhancement of Plutonium Concentration Above Pu(IV) Hydrous Oxide Because of Carbonate Complexation in $\mathrm{NaOH} / \mathrm{Na}_{2} \mathrm{CO}_{3}$ Solutions

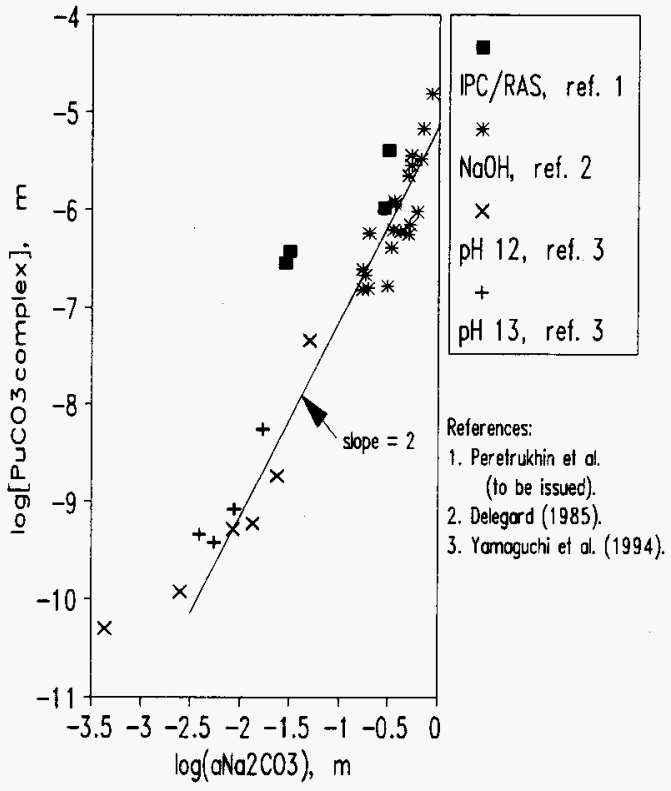

\subsubsection{Americium(III)}

The solubility of americium(III) hydroxide in 1.6 and $5.8 \mathrm{M} \mathrm{NaOH}$ was measured by IPC/RAS scientists to be ( 3.8 and 3.2) $\times 10^{-6} \mathrm{M}$, respectively (Peretrukhin et al. to be issued). The contact time was 72 hours and phase separation was by centrifugation.

Published results confirm the IPC/RAS findings. In Weaver and Shoun (1971), the observed solubility-limited concentration in water for Am(III) hydroxide was about $3.9 \times 10^{-6} \mathrm{M}$. These tests were conducted under argon cover gas, and the solubility was determined at about $\mathrm{pH}$ 8. The solid-liquid separation technique was not specified, and equilibration times were only minutes. In Pazukhin and Kochergin (1989), the solubility measured in aqueous solutions ranging from $\mathrm{pH} 8$ to $5 \mathrm{M} \mathrm{NaOH}$ was about $1.6 \times 10^{-6} \mathrm{M}$ and was practically independent of $\mathrm{pH}$, solid/solution ratio, and ionic strength. Equilibration times with the freshly-formed Am(III) hydroxide ranged from 0.5 to 1 hour, and centrifugation was used for phase separation. 
In contrast with these findings, however, americium concentrations in tests with aerated Hanford Site tank waste simulant solutions in the presence of low concentrations $\left(<10^{-5} \mathrm{M}\right)$ of organic complexants (EDTA ${ }^{7}$, HEDTA $^{8}$, citrate, and hydroxyacetate) was about $2 \times 10^{-8}$ $\mathrm{M}$; in the complete absence of organics, the Am concentrations were about $5 \times 10^{-9} \mathrm{M}$ (Delegard and Gallagher 1983). Contact time for these 1 to $4 \mathrm{M} \mathrm{NaOH}$ solutions was two weeks. The test solutions also contained nitrate, nitrite, carbonate, aluminate, fluoride, phosphate, and sulfate in varying concentrations. The oxidation state of americium was not identified or controlled in these tests. Americium(III) hydroxide solubility in solutions with $\mathrm{pH}$ between 10.5 and 13 were found to be invariant and about $10^{-10} \mathrm{M}$ (Rai et al. 1983).

Both ${ }^{241} \mathrm{Am}$ and ${ }^{243} \mathrm{Am}$ were used in these tests, and experiments were conducted in controlled atmosphere gloveboxes from which carbon dioxide and oxygen were excluded. Steady-state concentrations were obtained in a few days. Ultrafiltration (pore size 3 and $1.8 \mathrm{~nm}$, respectively) was used to separate phases in the tests by Delegard and Gallagher (1983) and Rai et al. (1983).

The differences in these results are large and significant. The transuranic waste threshold is $100 \mathrm{nCi}$ long-lived alpha activity per gram of waste. For ${ }^{241} \mathrm{Am}$ solutions, that threshold is equivalent to $1.2 \times 10^{-7} \mathrm{M}$ and lies between the high solubility findings of Peretrukhin et al. (to be issued) and the lower concentrations found by Delegard and Gallagher (1983) and Rai et al. (1983).

The markedly higher concentrations in the tests by Peretrukhin et al. (to be issued) and Pazukhin and Kochergin (1989) may be because phases were separated only by centrifugation. Thus, the presence of stable colloids that do not settle by centrifugation may explain the higher observed solubilities in these studies. Equilibration times also may have been too short to permit crystallization of the $\mathrm{Am}(\mathrm{OH})_{3}$. Further tests by the IPC/RAS, using the supplied ultrafilters (which are identical with those used by Rai et al. 1983), will be suggested to help resolve the differences.

\subsection{COPRECIPITATION}

The IPC/RAS investigated and reported using coprecipitation to remove neptunium and plutonium in their (V) and (VI) oxidation states from alkaline solutions. The bulk transition metal (hydr)oxide and sodium diuranate precipitants were prepared by homogeneous decomposition of alkali-soluble precursor compounds. The IPC/RAS scientists dubbed this process the "Method of Appearing Reagents" (Krot et al. 1996). The IPC/RAS work encompassed seven precipitants from eight soluble precursor complexes. Suitable comparisons of the coprecipitation behavior of neptunium and plutonium with manganese(IV) or (II) hydroxide were found in reported results of recent tests. The results of these coprecipitation tests with manganese are given in Table 6-1.

\footnotetext{
${ }^{7}$ EDTA is ethylenediaminetetraacetate.

${ }^{8}$ HEDTA is (N-2-hydroxyethyl)ethylenediaminetriacetate.
} 
Table 6-1. Neptunium and Plutonium Decontamination Factors from

Alkaline Solution and Genuine and Simulant Hanford Site Tank Waste.

\begin{tabular}{|c|c|c|c|}
\hline \multirow[b]{2}{*}{ 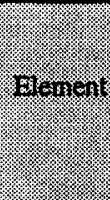 } & \multicolumn{3}{|c|}{ 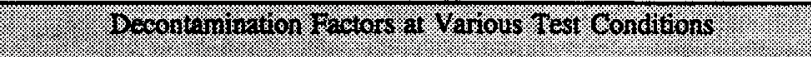 } \\
\hline & 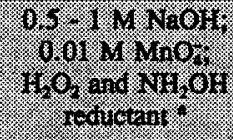 & 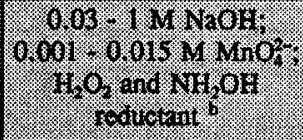 & 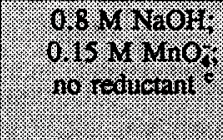 \\
\hline $\mathrm{Np}$ & 15 to 50 & 1 to 7 & -- \\
\hline $\mathrm{Pu}$ & 70 to 430 & 100 to 500 & 12 to 150 \\
\hline
\end{tabular}

Notes:

\footnotetext{
- Krot et al. (1996)

b Delegard (1995\%)

c Orth et al. (1995).
}

The tests performed by the IPC/RAS were with actinide-spiked $\mathrm{NaOH}$ solutions in which the added permanganate $\left(\mathrm{MnO}_{4}^{-}\right)$was caused to reduce and to precipitate as $\mathrm{MnO}_{2}$ and $\mathrm{Mn}(\mathrm{OH})_{2}$ with peroxide or hydroxylamine reductants, respectively. One comparison test used simulant and genuine Hanford Site tank wastes that had undergone calcination and dissolution treatment, then been treated with peroxide or hydroxylamine to reduce the manganate $\left(\mathrm{MnO}_{4}^{2-}\right)$ formed by calcination and dissolution processing to $\mathrm{Mn}(\mathrm{IV}$ ) precipitates (Delegard 1995a). The second comparison test involved genuine waste (from tank 241-SY-101) that had been treated with permanganate (Orth et al. 1995).

Solution decontamination factors for plutonium were high, especially for the experiments using reductants. Neptunium decontamination factors were much lower. In spite of the differences in the conditions under which the three studies were conducted, the experimental results were comparable.

In separate work, iron(II), (II), and (VI) precursor solutions have been tested to decontaminate simulated Hanford Site tank waste of neptunium, plutonium, and americium (Worl et al. 1995). Of these solutions, only the Fe(VI) precursor, which was tested only for Np(V), mirrored similar tests performed by the IPC/RAS (Krot et al. 1996). In both instances, neptunium coprecipitation was minimal. 


\subsection{GAMMA RADIATION CHEMISTRY}

The IPC/RAS investigated the effects of gamma radiolysis on the stability of neptunium, plutonium, and technetium in alkaline solution (Pikaev et al. to be issued). In particular, the stabilities of $10^{-4} \mathrm{M} \mathrm{Np}(\mathrm{VI}), \mathrm{Np}(\mathrm{V})$, and $\mathrm{Pu}(\mathrm{VI})$ in $\mathrm{NaOH}$ solutions under gamma irradiation were studied. Each actinide was chemically reduced by reactions in the bulk solution caused by gamma irradiation. The reduction yields were relatively insensitive to alkali concentration. For instance, the reduction yield of $\mathrm{Pu}(\mathrm{VI})$, irradiated to less than 1000 Grays $\left(10^{5} \mathrm{Rad}\right)$, was not changed by changing $\mathrm{NaOH}$ concentration in the range 1.3 to $6.9 \mathrm{M}$ $\mathrm{NaOH}$. However, the reductions were highly sensitive to the presence of organic materials in solution, with increased reduction yields even at trace organic concentrations.

The effects of the presence of nitrate $\left(\mathrm{NO}_{3}^{-}\right)$and nitrite $\left(\mathrm{NO}_{2}^{-}\right)$in the alkaline solutions also were investigated. With nitrate present, $N p(V I)$ is reduced to $N p(V)$, whereupon it reacts with radiolytically-produced peroxide and forms the $\mathrm{Np}(\mathrm{V})$ peroxide complex. The $\mathrm{Np}(\mathrm{V})$ peroxide complex was found to be unstable, however, if nitrite also was present. It was proposed by the IPC/RAS scientists that nitrite reacts with radiolytically-produced species (for example, $\mathrm{e}_{\mathrm{aq}}^{-}$and $\mathrm{O}^{-}$) to form species (for example, $\mathrm{NO}_{2}^{2-}$ and $\mathrm{NO}_{2}$ ) which react to destroy radiolytically-produced peroxide. Complete reduction of $\mathrm{Np}(\mathrm{V})$ to $\mathrm{Np}(\mathrm{IV})$ did not occur if nitrate and/or nitrite were present. In contrast with the behavior of neptunium, plutonium(VI) was reduced to Pu(IV) even in the presence of nitrite. The analogous peroxide complex was not observed.

Karraker (1995) examined the effect of gamma irradiation ( $5 \times 10^{4}$ Gray) on the stability of $\mathrm{Pu}(\mathrm{VI})$ hydroxide (as determined by reduction to $\mathrm{Pu}(\mathrm{IV})$ hydrous oxide) in solutions ranging from 2 to $10 \mathrm{M} \mathrm{NaOH}$. It was found that irradiation reduced $\mathrm{Pu}(\mathrm{VI})$ at lower hydroxide concentrations but had no effect at higher concentrations ( 8 to $10 \mathrm{M} \mathrm{NaOH}$ ). These findings are in contrast to those of Pikaev et al. (to be issued) who found $\mathrm{Pu}(\mathrm{VI})$ reduction yields by irradiation unaffected by $\mathrm{NaOH}$ concentration in the range of 1.3 to $6.9 \mathrm{M} \mathrm{NaOH}$.

Karraker (1995) determined the effect of $6 \times 10^{4}$ Gray irradiation on the Pu(VI)-spiked mixed $\mathrm{NaOH} / \mathrm{NaNO}_{3} / \mathrm{NaNO}_{2}$ solutions. Irradiation decreased plutonium concentrations for those experiments conducted at 1 or $2 \mathrm{M} \mathrm{NaOH}$ (nitrate and nitrite concentrations were 2 to $4 \mathrm{M}$ and 0.45 to $1.5 \mathrm{M}$, respectively). At $4 \mathrm{M} \mathrm{NaOH}$ (and $2.5 \mathrm{M}$ each nitrate and nitrite), plutonium concentration was increased somewhat above that observed in unirradiated control samples. These findings agree with the limited results presented by Pikaev et al. (to be issued).

Finally, Karraker (1995) examined the effect of initial plutonium valence on the products formed by gamma irradiation $\left(5 \times 10^{4} \mathrm{Gray}\right)$ in $\mathrm{NaOH}$ ranging from 2 to $10 \mathrm{M}$. Tests began with Pu(TV), Pu(VI), and mixed Pu(IV)/Pu(VI) tracers. After irradiation, the soluble plutonium in all experiments was present almost exclusively as $\mathrm{Pu}(\mathrm{VI})$. Control samples contained both $\mathrm{Pu}(\mathrm{IV})$ and $\mathrm{Pu}(\mathrm{VI})$ (with increasing $\mathrm{Pu}(\mathrm{VI})$ fraction as $\mathrm{NaOH}$ concentration increased) when Pu(IV) spike was used. For the control samples with the Pu(VI) spike and the mixed valence spike, the dissolved plutonium was hexavalent. Irradiation clearly 
decreased plutonium solubility at 2 to $6 \mathrm{M} \mathrm{NaOH}$ for all experiments containing $\mathrm{Pu}(\mathrm{VI})$ in the initial spike. These results agree with the findings of Pikaev et al. (to be issued). Plutonium solution concentrations in the irradiated solutions containing $\mathrm{Pu}(\mathrm{IV})$ spike were generally higher than the control samples. These results agree with findings of an earlier study by Karraker (1994a).

In that earlier study, the effects of gamma irradiation on the solubility of Pu(IV) hydrous oxide in $\mathrm{NaOH}$ solutions in the presence and absence on nitrate and nitrite were examined Karraker 1994a). In $\mathrm{NaOH}$ solutions without nitrate or nitrite, irradiation increased plutonium solution concentrations. The increase was greater as hydroxide concentration increased. With nitrate or nitrite present, particularly at higher concentrations, gamma irradiation had no discernible effect on plutonium solution concentration.

Results of the studies of Pikaev et al. (to be issued) and Karraker (1994a) are not directly comparable. However, both studies showed nitrate and nitrite did not alter the effects of gamma irradiation on plutonium concentration in strongly alkaline solution. 
WHC-SP-1184

This page intentionally left blank. 


\subsection{REFERENCES}

Bourges, J., 1972, "Preparation et Identification du Plutonium a l'Etat d'Oxydation-V en Milieu Basique," Radiochem. Radioanal. Letters, 12(2-3), pp. 111-119.

Delegard, C. H., and S. A. Gallagher, 1983, Effects of Hanford High-Level Waste Components on the Solubility of Cobalt, Strontium, Neptunium, Plutonium, and Americium, Rockwell Hanford Operations, Richland, Washington.

Delegard, C. H., 1985, Solubility of $\mathrm{PuO}_{2} \cdot \mathrm{XH}_{2} \mathrm{O}$ in Alkaline Hanford High-Level Waste Solution, RHO-RE-SA-75 P, Rockwell Hanford Operations, Richland, Washington. Also published in Radiochimica Acta 41, pp. 11-21 (1985).

Delegard, C. H., 1995a, Calcination/Dissolution Chemistry Development: FY 1995, WHC-EP-0882, Westinghouse Hanford Company, Richland, Washington.

Delegard, C. H., 1995b, Liaison Activities with the Institute of Physical Chemistry, Russian Academy of Science: FY 1995, WHC-SP-1166, Westinghouse Hanford Company, Richland, Washington.

Delegard, C. H., 1996, Calcination/Dissolution of Hanford Site Tank Waste, WHC-SA-2911-VA, Westinghouse Hanford Company, Richland, Washington.

Karraker, D. G., 1995, Plutonium(VI) Solubility Studies in Savannah River Site High-Level Waste Supernate, WSRC-TR-95-0244, Savannah River Technical Center, Aiken, South Carolina.

Karraker, D. G., 1994a, Radiation Effects on the Solubility of Plutonium in Alkaline High Level Waste, WSRC-MS-94-0278X (Rev. 2), Savannah River Technical Center, Aiken, South Carolina.

Karraker, D. G., 1994b, Solubility of Neptunium in Alkaline High Level Waste, WSRC-TR-94-0526, Rev. 1, Savannah River Technical Center, Aiken, South Carolina.

Krot, N., V. Shilov, A. Bessonov, N. Budantseva, I. Charushnikova, V. Perminov, and L. Astafurova, 1996, Investigation on the Coprecipitation of Transuranium Elements from Alkaline Solutions by the Method of Appearing Reagents, WHC-EP-0898, Westinghouse Hanford Company, Richland, Washington.

Maslennikov, A. G., V. F. Peretrukhin, and F. David, 1993, Proceedings of the Finnish Russian Symposium on Radiochemistry, S. Kulmala, editor, Helsinki, Finland, p. 12. 
Orth, R. J., A. H. Zacher, A. J. Schmidt, M. R. Elmore, K. R. Elliott, G. G. Neuenschwander, and S. R. Gano, 1995, Removal of Strontium and Transuranics from Hanford Tank Waste via Addition of Metal Cations and Chemical Oxidant FY 1995 Test Results, PNL-10766, Pacific Northwest Laboratory, Richland, Washington.

Pazukhin, E. M., and S. M. Kochergin, 1989, "Stability Constants of Hydrolyzed Forms of Americium(III) and Solubility Product of Its Hydroxide," Soviet Radiochemistry 31(4), pp. $430-436$.

Peretroukhin, V. F., I. G. Tananaev, S. V. Kryutchkov, V. I. Silin, and C. H. Delegard, 1995, Solubility of Transuranium Elements and Technetium Hydroxide Compounds in $\mathrm{NaOH}$ Solutions in the Presence of Redox- and Complexing Agents, WHC-SA-2921-A, Westinghouse Hanford Company, Richland, Washington.

Peretrukhin, V. F., and D. P. Alekseeva, 1974, "Polarographic Properties of Higher Oxidation States of Plutonium in Aqueous Alkali Solutions," Soviet Radiochemistry

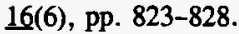

Peretrukhin, V. F., F. David, and A. Maslennikov, 1983, "Electrochemical Properties and Thermodynamic Stability of Pu and Neighbouring Actinides in the (IV) and (V) Oxidation States in Aqueous Alkaline Media and Radwastes," 1994, Radiochimica Acta 65, pp. 161-166.

Peretrukhin, V. F., V. P. Shilov, and A. K. Pikaev, 1995, Alkaline Chemistry of Transuranium Elements and Technetium and the Treatment of Alkaline Radioactive Wastes, WHC-EP-0817, Westinghouse Hanford Company, Richland, Washington.

Peretrukhin, V. F., S. V. Kryutchkov, V. I. Silin, I. G. Tananaev, V. I. Belyaeva, V. E. Trushina, S. I. Ushakov, and M. S. Grigor'ev, to be issued, Determination of the Solubility of $N p(I V)-(V I), P u(I I I)-(V I), A m(I I I)-(V)$, and $T c(I V),(V)$ Hydroxo Compounds in 0.5 - $14 \mathrm{M} \mathrm{NaOH}$ Solutions, WHC-EP-0897, Westinghouse Hanford Company, Richland, Washington.

Peretrukhin, V. F., and V. I. Spitsyn, 1982, "Electrochemical Determination of the Oxidation Potentials and the Thermodynamic Stability of the Valence States of the Transuranium Elements in Aqueous Alkaline Media," Bulletin of the Academy of Sciences, Division of the Chemical Sciences, (4), pp. 726-730.

Pikaev, A. K., A. V. Gogolev, S. V. Kryutchkov, V. P. Shilov, V. N. Chulkov, L. I. Belyaeva, and L. N. Astafurova, to be issued, Radiolysis of Actinides and Technetium in Alkaline Media, WHC-EP-0901, Westinghouse Hanford Company, Richland, Washington. 
Rai, D., R. G. Strickert, D. A. Moore, and J. L. Ryan, 1983, "Am(III) Hydrolysis Constants and Solubility of Am(III) Hydroxide," Radiochimica Acta 33, pp. 201-206.

Shilov, V. P., N. N. Krot, N. Budantseva, A. Yusov, A. Garnov, V. Perminov, and L. Astafurova, 1996, Investigation of Some Redox Reactions of Neptunium, Plutonium, Americium, and Technetium in Alkaline Media, WHC-EP-0886, Westinghouse Hanford Company, Richland, Washington.

Tananaev, I. G., 1989, "Forms of Existence of Hexavalent Plutonium and Americium in Aqueous Alkaline Solutions," Soviet Radiochemistry 31(3), pp. 303-307.

Tananaev, I. G., 1990, "Forms of Neptunium(V) and Americium(V) in Basic Aqueous Media," Soviet Radiochemistry 32(5), pp. 476-479.

Tananaev, I. G., 1994, "Speciation of $N p(V)$ in Solutions of Tetraalkylammonium Hydroxides," Radiochemistry 36(1), pp. 15-18.

Weaver, B., and R. R. Shoun, 1971, "Basicities of Trivalent Actinides and Lanthanides and Solubilities of Their Hydroxides," in Proceedings of the $g^{\text {th }}$ Rare Earth Research Conference, October 10 to 14, 1971, Blacksburg, Virginia, USAEC Report CONF-711001-(Vol. 1), p. 322. Also published in The Chemistry of Americium, W. W. Schulz, Energy Research and Development Administration, Technical Information Center, Oak Ridge, Tennessee, p. 149 (1976).

Worl, L. A., S. M. Bowen, J. M. Berg, D. D. Padilla, and M. R. Cisneros, 1995, Actinide Removal from Hanford Supernatant Tank Waste, LA-UR-95-3743, Los Alamos National Laboratory, Los Alamos, New Mexico.

Yamaguchi, T., Y. Sakamoto, and T. Ohnuki, 1994, "Effect of the Complexation on Solubility of Pu(IV) in Aqueous Carbonate System," Radiochimica Acta 66/67, pp. 9-14. 
This page intentionally left blank. 


\section{DISTRIBUTION}

Number of Copies

\section{OFFSITE}

1

1

Oak Ridge National Laboratory

Oak Ridge, TN 37831-6178
P. O. Box 2008

U.S. Department of Energy

12800 Middlebrook Road

Trevion II Building

Germantown, MD 20874

K. Gerdes

J. S. Watson

\section{ONSITE}

1

SAIC

D. J. Swanberg

HO-50

3

Pacific Northwest National Laboratory

J. M. Gephart

K2-21

W. L. Kuhn (2)

K2-21

3

U.S. Department of Energy

Richland Field Operations

J. A. Frey

K8-50

J. P. Hanson

K8-50

B. A. Mauss

K8-50 


\section{DISTRIBUTION}

Number of Copies

ONSITE

17

Westinghouse Hanford Company

J. D. Berger

H6-34

B. T. Berlin

H6-34

C. H. Delegard (10)

G. B. Griffin

J. R. Jewett

J. A. Smart

DPC

Central Files
T6-09

T6-16

T6-09

R1-08

A3-94

A3-88 